$\begin{array}{rr}\text { FIT(PPATOLOGI } & \text { Volume } 11, \text { Nomor 4, Agustus } 2015 \\ \text { IN D ONESIA } & \text { Halaman } 121-127 \\ \text { ISSN: } 0215-7950 & \text { DOI: } 10.14692 / \text { ji.11.4.121 }\end{array}$

\title{
Deteksi Virus Utama Bawang Merah dan Bawang Putih dari Daerah Jawa Barat dan Jawa Tengah
}

\author{
Detection of Main Viruses Infecting Shallot and Garlic in \\ West and Central Java
}

\author{
Kadwati, Sri Hendrastuti Hidayat* \\ Institut Pertanian Bogor, Bogor 16680
}

\begin{abstract}
ABSTRAK
Penyakit yang disebabkan oleh virus merupakan salah satu kendala dalam meningkatkan produksi bawang merah (Allium cepa) dan bawang putih (A. sativum). Penelitian dilakukan untuk mendeteksi virus utama bawang merah dan bawang putih dari pertanaman di lapangan dan dari umbinya menggunakan antibodi dengan metode ELISA. Sampel daun dan umbi diperoleh dari pertanaman bawang di Jawa Barat (Bandung, Bogor, dan Cirebon), Jawa Tengah (Brebes) serta Yogyakarta (Bantul). Infeksi Garlic common latent virus (GCLV), Shallot latent virus (SLV), dan Potyvirus berhasil dideteksi menggunakan antibodi spesifik. Ketiga jenis virus menginfeksi secara tunggal maupun bersama-sama (infeksi campuran). Rata-rata persentase infeksi virus di pertanaman berkisar $11.2-14.3 \%$ pada bawang merah dan $14.3 \%$ pada bawang putih; sedangkan pada sampel umbi berkisar $11.2-13.3 \%$ pada bawang merah, dan $9.18 \%$ pada bawang putih.
\end{abstract}

Kata kunci: Garlic common latent virus, ELISA, Potyvirus, Shallot latent virus

\begin{abstract}
Viral disease has been reported to cause significant effect on production of shallot (A. cepa) and garlic (A. sativum). The study was conducted to detect main viruses from leaves and bulbs of shallot and garlic using specific antibodies by ELISA method. Leaf and bulb samples was collected from West Java (Bandung, Bogor and Cirebon), Central Java (Brebes), and Yogyakarta (Bantul). Single as well as mix infection of GCLV, SLV, and Potyvirus was successfully detected using specific antibodies. The average percentage of virus infection in the crop ranged from $11.2-14.3 \%$ on shallot, and $14.3 \%$ on garlic; whereas in the bulb ranged from $11.2-13.3 \%$ on shallot, and $9.18 \%$ on garlic.
\end{abstract}

Key words: Garlic common latent virus, ELISA, Potyvirus, Shallot latent virus

*Alamat penulis korespondensi: Departemen Proteksi Tanaman, Fakultas Pertanian, Institut Pertanian Bogor, Jalan Kamper, Kampus Darmaga IPB, Bogor 16680

Tel: 0251-8629364, Faks: 0251-8629362, Surel: srihendrastutihidayat@gmail.com 


\section{PENDAHULUAN}

Produksi bawang merah (Allium cepa) dan bawang putih (A. sativum) di Indonesia cenderung mengalami fluktuasi dari tahun ke tahun (BPS 2013). Faktor penentu produksi bawang merah dan bawang putih secara nasional ialah lahan yang semakin sempit, perhatian terhadap infrastruktur pascapanen, pengetahuan budi daya dan teknologi petani, keadaan iklim yang tidak menentu, umbi atau benih berkualitas tinggi di pasaran, dan faktor biotik terutama gangguan oleh organisme pengganggu tanaman (OPT).

Bawang merah dan bawang putih di Indonesia selalu diperbanyak secara vegetatif sehingga potensi virus yang ditularkan melalui umbi sangat tinggi. Virus tular umbi benih yang dapat menyebabkan penyakit pada tanaman bawang di antaranya ialah Shallot latent virus (SLV) dan Onion yellow dwarf virus (OYDV) (Torrico et al. 2010; Bagi et al. 2012). Kelompok virus yang umum menginfeksi tanaman bawang-bawangan berasal dari genus Carlavirus, Potyvirus, dan Allexivirus. Virus utama pada tanaman bawang di antaranya SLV dan Garlic common latent virus (GCLV) anggota Carlavirus; OYDV, Shallot yellow stripe virus (SYSV), dan Leek yellow stripe virus (LYSV) anggota Potyvirus; Mite-born filamentous virus (MbFV) anggota Allexivirus (Diekmann 1997).

Metode serologi Dot immunobinding assay (DIBA) dan Enzyme-linked immunosorbent assay (ELISA) serta metode molekuler Reverse transcription-polymerase chain reaction (RTPCR) umum dilakukan untuk mendeteksi virus bawang. Gunaeni et al. (2011) melaporkan adanya infeksi OYDV (85\%), SYSV (95\%), dan gabungan OYDV dan SYSV (85\%) pada 13 varietas bawang merah asal Jawa Barat dan Jawa Tengah menggunakan metode serologi Direct-ELISA. Kenyataan masih kurangnya informasi mengenai jenis-jenis virus yang menginfeksi tanaman bawang di Indonesia menjadi latar belakang penelitian ini.

Penelitian bertujuan mendeteksi keberadaan virus utama bawang merah dan bawang putih dari sentra pertanaman bawang di daerah
Jawa Barat dan Jawa Tengah dengan metode ELISA dan menentukan persentase infeksi virus di lapangan dan infeksi virus terbawa umbi benih.

\section{BAHAN DAN METODE}

\section{Pengambilan Sampel Bawang}

Sampel daun diambil dari pertanaman bawang merah dan bawang putih di Jawa Barat (Desa Cikole, Kecamatan Lembang, Kabupaten Bandung dan Desa Alamendah, Kecamatan Rancabali, Kabupaten Bandung), Yogyakarta (Desa Sri Gading, Kecamatan Sanden, Kabupaten Bantul), dan Jawa Tengah (Desa Pengabean, Kecamatan Losari, Kabupaten Brebes dan Desa Pangenan, Kecamatan Pangenan, Kabupaten Cirebon). Sampel diambil secara purposive sampling dari masing-masing lokasi sebanyak 35 sampel daun yang menunjukkan gejala penyakit yang diduga disebabkan oleh virus: mosaik kuning, mosaik hijau muda, bergaris kuning, daun pipih bergaris kuning pucat di tengah, keriting, bercak kuning, dan permukaan atas daun berlekuk.

Sampel umbi diperoleh dari petani di Jawa Tengah (Desa Tanjung, Kecamatan Tanjung, Kabupaten Brebes, dan Desa Pangenan, Kecamatan Pangenan, Kabupaten Cirebon), dan dari pasar di Jawa Barat (Desa Bara, Kecamatan Darmaga, Kabupaten Bogor). Pengambilan sampel dilakukan secara acak karena tidak diketahui gejala infeksi virus pada umbi. Selanjutnya, 50 sampel umbi yang diambil dari masing-masing lokasi ditanam dengan memotong $1.5 \mathrm{~cm}$ bagian ujung umbi untuk mempercepat pertumbuhan. Umbi ditanam pada baki semai menggunakan medium tanam tanah dan pupuk dan dipelihara di rumah kasa selama 24 hari atau sampai muncul daun tunas.

\section{Deteksi Virus}

Sampel daun dan umbi sebanyak $0.1 \mathrm{~g}$ untuk masing-masing sampel dimasukkan ke dalam kantong plastik, selanjutnya disimpan pada suhu $-80{ }^{\circ} \mathrm{C}$ atau langsung digunakan untuk deteksi virus dengan metode ELISA. 
Deteksi virus menggunakan 3 jenis antibodi secara terpisah, yaitu 2 antibodi spesifik GCLV dan SLV, dan antibodi umum Potyvirus. Cairan perasan sampel daun disiapkan dengan menggerus $0.1 \mathrm{~g}$ daun dalam bufer ekstraksi $(\mathrm{pH}$ 7.4) $[200 \mathrm{~mL}$ PBST $+2 \%$ polyvinyl pyrrolidone (PVP)] dengan perbandingan 1:10 (b:v). Metode ELISA untuk masingmasing antibodi mengikuti pedoman yang dianjurkan untuk masing-masing kit (DSMZ, Jerman), yaitu metode double antibody sandwich (DAS)-ELISA untuk GCLV, metode triple antibody sandwich (TAS)-ELISA untuk SLV, dan metode indirect (I)-ELISA untuk Potyvirus. Reaksi positif ditentukan berdasarkan pada hasil pengukuran nilai absorbansi (NA) menggunakan spektrofotometer pada panjang gelombang $405 \mathrm{~nm}$, yaitu NA sampel lebih besar atau sama dengan $2 \times$ NA kontrol negatif. Hasil deteksi kemudian digunakan untuk menentukan persentase infeksi virus, yaitu nisbah antara jumlah sampel terinfeksi dan jumlah total sampel yang diuji $(\times 100 \%)$.

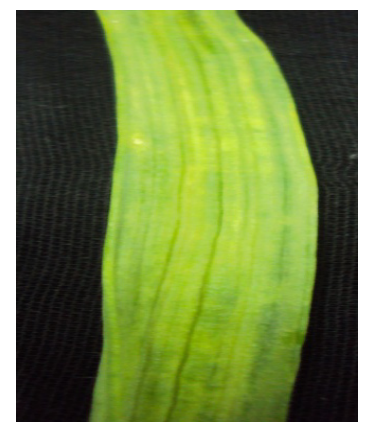

a

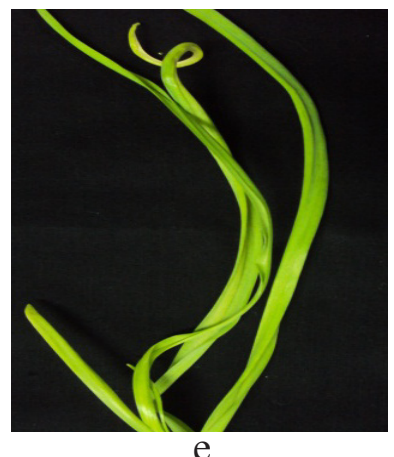

e

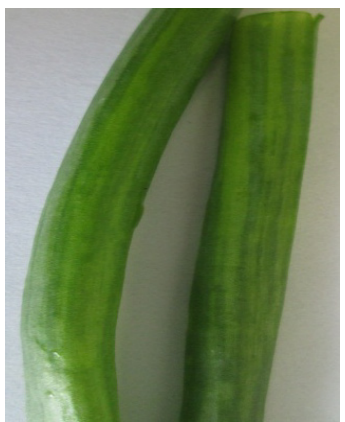

b

\section{HASIL}

\section{Gejala Infeksi Virus pada Tanaman Bawang di Lapangan}

Sampel bawang yang diperoleh dari daerah Jawa Barat dan Jawa Tengah menunjukkan gejala infeksi virus yang berbeda-beda. Gejala tersebut dapat dikelompokkan menjadi 7 jenis, yaitu gejala mosaik kuning, mosaik hijau muda, bergaris kuning, daun pipih bergaris kuning pucat di tengah, keriting, bercak kuning, dan permukaan atas daun berlekuk (Gambar 1). Gejala yang paling dominan ialah mosaik kuning dan bergaris kuning yang diperoleh dari semua sampel bawang merah (Bandung, Bantul, Brebes, dan Cirebon), sedangkan jenis gejala yang paling sedikit ditemukan ialah gejala permukaan atas daun berlekuk yang hanya ditemukan pada sampel bawang putih dari Bandung. Keragaman gejala tertinggi ditemukan pada sampel bawang merah dari daerah Brebes dengan 5 jenis gejala (mosaik kuning, mosaik hijau muda, bergaris kuning, daun pipih bergaris kuning pucat di tengah, dan keriting), sedangkan keragaman gejala
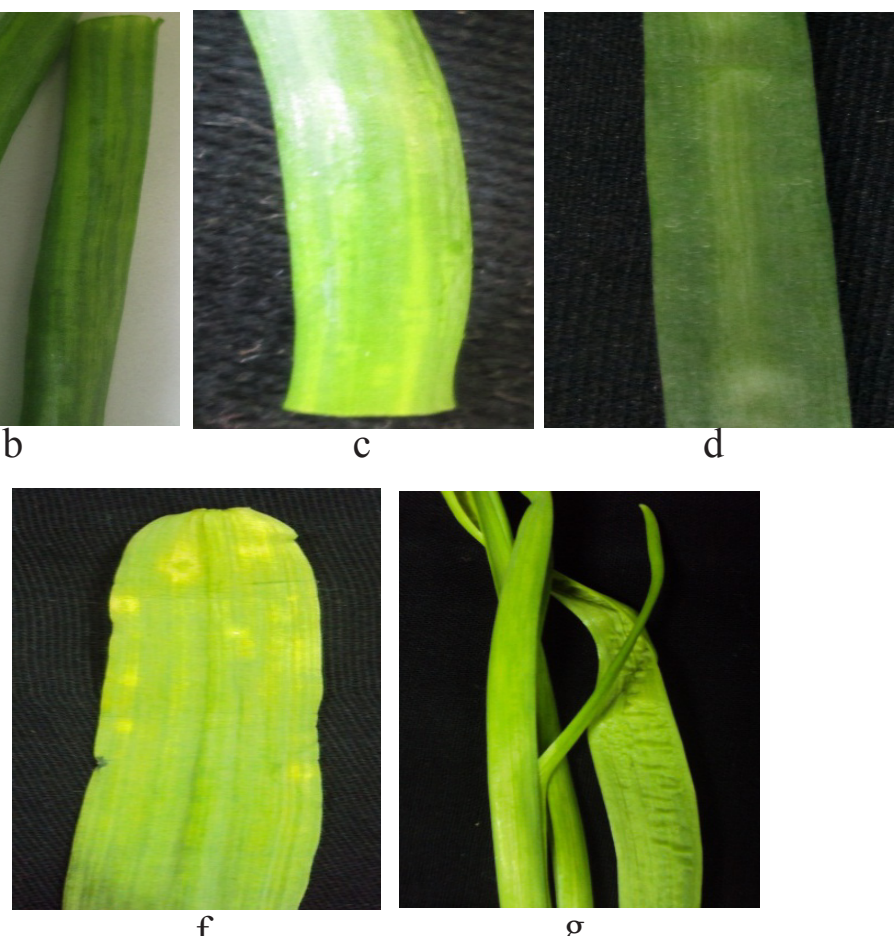

g

Gambar 1 Gejala penyakit pada sampel daun bawang merah. a, mosaik kuning; b, mosaik hijau muda; c, bergaris kuning; d, daun pipih bergaris kuning pucat di tengah; e, keriting. Gejala penyakit pada sampel daun bawang putih. f, bercak kuning dan; g, permukaan atas daun berlekuk. 
terendah ditemukan pada bawang merah asal Bandung dengan 3 jenis gejala (mosaik kuning, bergaris kuning, dan daun pipih bergaris kuning pucat di tengah).

\section{Deteksi Virus pada Sampel Daun dari Lapangan}

Tiga jenis virus, yaitu GCLV, SLV, dan Potyvirus berhasil dideteksi dari lapangan baik secara tunggal maupun bersama-sama (infeksi campuran) (Tabel 1). Sampel dengan gejala mosaik kuning terinfeksi oleh ke-3 virus, baik sebagai infeksi tunggal, ganda, maupun campuran 3 virus. Selain pada gejala mosaik kuning, jenis infeksi tunggal dan campuran ke-3 virus sangat bervariasi. Infeksi tunggal oleh Potyvirus ditemukan pada semua sampel, infeksi GCLV hanya terdapat pada sampel bawang merah asal Bandung, infeksi SLV ditemukan pada sampel bawang merah asal Bandung, Bantul, dan Cirebon. Infeksi ganda SLV dan Potyvirus tidak terdeteksi pada bawang merah asal Bandung, infeksi ganda tersebut ditemukan pada sampel bawang merah asal Bantul, Brebes, dan Cirebon, serta sampel bawang putih asal Bandung. Infeksi ganda GCLV dan Potyvirus hanya ditemukan pada sampel bawang putih asal Bandung, sedangkan infeksi ganda GCLV dan SLV tidak ditemukan sama sekali pada semua sampel. Infeksi campuran 3 virus GCLV, SLV, dan
Potyvirus ditemukan pada sampel bawang merah asal Bantul dan Brebes, serta bawang putih asal Bandung (Tabel 2).

Rata-rata insidensi virus target dari masing-masing daerah asal sampel berkisar antara terendah $11.22 \%$ (bawang merah asal Bandung) dan tertinggi 14.29\% (bawang merah asal Brebes dan Cirebon serta bawang putih asal Bandung) (Tabel 2). Infeksi tertinggi pada bawang merah berturut-turut disebabkan oleh Potyvirus (30.4\%); SLV dan Potyvirus (28.6\%); GCLV, SLV, dan Potyvirus (14.3\%); GCLV (8.9\%), dan SLV (8.9\%); sedangkan infeksi ganda GCLV dan SLV serta GCLV dan Potyvirus tidak terdeteksi pada semua sampel. Kondisi yang berbeda ditemukan pada bawang putih, yaitu infeksi tertinggi berturutturut disebabkan oleh GCLV dan Potyvirus (42.9\%); GCLV, SLV, dan Potyvirus (42.9\%); SLV dan Potyvirus (7.1\%); Potyvirus (7.1\%); sedangkan infeksi tunggal GCLV, SLV, dan infeksi ganda GCLV dan SLV tidak terdeteksi pada semua sampel (Tabel 2).

\section{Deteksi Virus pada Sampel Umbi}

Seperti halnya pada sampel daun lapangan, sampel umbi bawang merah dan bawang putih terinfeksi lebih dari 1 virus. Sampel umbi bawang merah asal Brebes dan bawang putih asal Bogor terinfeksi GCLV dan SLV secara tunggal, sedangkan infeksi tunggal Potyvirus

Tabel 1 Hasil deteksi virus dari sampel tanaman bawang berdasarkan reaksi ELISA

\begin{tabular}{lccccccc}
\hline & \multicolumn{8}{c}{ Jenis virus } \\
\cline { 2 - 8 } $\begin{array}{l}\text { Jenis } \\
\text { gejala }\end{array}$ & GCLV & SLV & Potyvirus & $\begin{array}{c}\text { GCLV, } \\
\text { SLV }\end{array}$ & $\begin{array}{c}\text { GCLV, } \\
\text { Potyvirus }\end{array}$ & $\begin{array}{c}\text { SLV, } \\
\text { Potyvirus }\end{array}$ & $\begin{array}{c}\text { GCLV, SLV, dan } \\
\text { Potyvirus }\end{array}$ \\
\hline MK & + & + & + & + & + & + & + \\
MH & - & - & + & - & - & - & + \\
GK & + & - & + & + & + & + & + \\
PB & - & - & + & - & + & + & - \\
K & + & + & - & + & - & + & + \\
BK & - & - & + & - & - & + & + \\
AB & - & + & + & + & + & + & + \\
\hline
\end{tabular}

Jenis gejala: MK, Mosaik kuning; MH, Mosaik hijau muda; GK, Bergaris kuning; PB, Pipih bergaris kuning pucat di tengah; K, Keriting; BK, Bercak kuning; AB, Permukaan atas daun berlekuk.

Jenis virus: GCLV, Garlic common latent virus; SLV, Shallot latent virus.

Reaksi ELISA : (+), positif; (-), negatif. 
Tabel 2 Frekuensi insidensi virus pada sampel daun bawang dari lapangan berdasarkan hasil deteksi dengan metode ELISA

\begin{tabular}{|c|c|c|c|c|c|c|c|c|c|}
\hline \multirow{2}{*}{$\begin{array}{l}\text { Jenis } \\
\text { dan asal } \\
\text { sampel } \\
\text { lapangan }\end{array}$} & \multirow[b]{2}{*}{ Varietas } & \multicolumn{7}{|c|}{$\sum$ sampel positif ELISA/ $\sum$ sampel yang diuji (\%) } & \multirow{2}{*}{$\begin{array}{c}\text { Rata-rata } \\
\text { insidensi } \\
\text { virus } \\
\text { pada } \\
\text { masing- } \\
\text { masing } \\
\text { lokasi }\end{array}$} \\
\hline & & GCLV & SLV & Potyvirus & $\begin{array}{c}\text { GCLV, } \\
\text { SLV }\end{array}$ & $\begin{array}{l}\text { GCLV, } \\
\text { Potyvirus }\end{array}$ & $\begin{array}{c}\text { SLV, } \\
\text { Potyvirus }\end{array}$ & $\begin{array}{l}\text { GCLV, } \\
\text { SLV, dan } \\
\text { Potyvirus }\end{array}$ & \\
\hline $\begin{array}{l}\text { BM } \\
\text { Bandung }\end{array}$ & $\begin{array}{l}\text { Maja dan } \\
\text { Trisula }\end{array}$ & $\begin{array}{c}5 / 14 \\
(35.7)\end{array}$ & $\begin{array}{c}2 / 14 \\
(14.3)\end{array}$ & $\begin{array}{c}4 / 14 \\
(28.6)\end{array}$ & $\begin{array}{c}0 / 14 \\
(0)\end{array}$ & $\begin{array}{c}0 / 14 \\
(0)\end{array}$ & $\begin{array}{c}0 / 14 \\
(0)\end{array}$ & $\begin{array}{c}0 / 14 \\
(0)\end{array}$ & 11.2 \\
\hline $\begin{array}{l}\text { BM } \\
\text { Bantul }\end{array}$ & $\begin{array}{c}\text { Crok } \\
\text { kuning } \\
\text { dan Biru }\end{array}$ & $\begin{array}{c}0 / 14 \\
(0)\end{array}$ & $\begin{array}{c}2 / 14 \\
(14.3)\end{array}$ & $\begin{array}{c}8 / 14 \\
(57.1)\end{array}$ & $\begin{array}{c}0 / 14 \\
(0)\end{array}$ & $\begin{array}{c}0 / 14 \\
(0)\end{array}$ & $\begin{array}{c}1 / 14 \\
(7.14)\end{array}$ & $\begin{array}{l}1 / 14 \\
(7.1)\end{array}$ & 12.2 \\
\hline $\begin{array}{l}\text { BM } \\
\text { Brebes }\end{array}$ & $\begin{array}{l}\text { Bima } \\
\text { curut }\end{array}$ & $\begin{array}{c}0 / 14 \\
(0)\end{array}$ & $\begin{array}{c}0 / 14 \\
(0)\end{array}$ & $\begin{array}{l}1 / 14 \\
(7.1)\end{array}$ & $\begin{array}{c}0 / 14 \\
(0)\end{array}$ & $\begin{array}{l}0 / 14 \\
(0)\end{array}$ & $\begin{array}{l}13 / 14 \\
(92.9)\end{array}$ & $\begin{array}{l}0 / 14 \\
(0)\end{array}$ & 14.3 \\
\hline $\begin{array}{l}\text { BM } \\
\text { Cirebon }\end{array}$ & $\begin{array}{l}\text { Bima } \\
\text { curut }\end{array}$ & $\begin{array}{c}0 / 14 \\
(0)\end{array}$ & $\begin{array}{l}1 / 14 \\
(7.1)\end{array}$ & $\begin{array}{c}4 / 14 \\
(28.6)\end{array}$ & $\begin{array}{l}0 / 14 \\
(0)\end{array}$ & $\begin{array}{l}0 / 14 \\
(0)\end{array}$ & $\begin{array}{c}2 / 14 \\
(14.3)\end{array}$ & $\begin{array}{l}7 / 14 \\
(50)\end{array}$ & 14.3 \\
\hline $\begin{array}{l}\text { Rata-rata } \\
\text { virus targe } \\
\text { bawang } \mathrm{m}\end{array}$ & $\begin{array}{l}\text { nfeksi } \\
\text { t pada } \\
\text { erah }\end{array}$ & 8.9 & 8.9 & 30.4 & 0 & 0 & 28.6 & 14.3 & \\
\hline $\begin{array}{l}\text { BP } \\
\text { Bandung }\end{array}$ & Lokal & $\begin{array}{l}0 / 14 \\
(0)\end{array}$ & $\begin{array}{l}0 / 14 \\
(0)\end{array}$ & $\begin{array}{l}1 / 14 \\
(7.1)\end{array}$ & $\begin{array}{l}0 / 14 \\
(0)\end{array}$ & $\begin{array}{c}6 / 14 \\
(42.9)\end{array}$ & $\begin{array}{c}1 / 14 \\
(7.14)\end{array}$ & $\begin{array}{c}6 / 14 \\
(42.9)\end{array}$ & 14.3 \\
\hline
\end{tabular}

BM, bawang merah; BP, bawang putih

ditemukan pada sampel bawang merah asal Bogor, Brebes, dan Cirebon. Infeksi ganda GCLV dan SLV ditemukan pada sampel bawang merah asal Brebes dan bawang putih asal Bogor. Infeksi SLV dan Potyvirus ditemukan pada sampel umbi bawang merah Cirebon dan Bogor serta bawang putih Bogor. Infeksi GCLV dan Potyvirus hanya terdeteksi pada sampel umbi bawang merah asal Brebes, sedangkan infeksi campuran GCLV, SLV dan Potyvirus ditemukan pada sampel umbi bawang merah asal Brebes, Cirebon, dan bawang putih asal Bogor (Tabel 3).

Rata-rata infeksi virus target dari masingmasing daerah asal sampel umbi berkisar antara terendah 9.18\% (bawang putih asal Bogor) sampai tertinggi $13.27 \%$ (bawang merah asal Bogor dan Brebes) (Tabel 3). Infeksi tertinggi pada umbi bawang merah berturut-turut disebabkan oleh SLV dan Potyvirus (33.3\%); Potyvirus (21.4\%); GCLV, SLV, dan Potyvirus (19\%); GCLV dan Potyvirus (7.1\%); GCLV dan SLV (2.4\%); GCLV (2.4\%); SLV (2.4\%). Infeksi tertinggi pada umbi bawang putih berturut-turut disebabkan oleh SLV (28.6\%);
SLV dan Potyvirus (14.3\%); GCLV (7.1\%); GCLV dan SLV (7.1\%); GCLV, SLV, dan Potyvirus (7.1\%); sedangkan infeksi tunggal Potyvirus dan infeksi ganda GCLV dan Potyvirus tidak ditemukan pada semua umbi.

\section{PEMBAHASAN}

Infeksi virus pada tanaman bawang merah dan bawang putih umumnya menyebabkan gejala mosaik bergaris hijau dan bergaris kuning. Gejala serupa dilaporkan oleh Gunaeni et al. (2011) pada bawang merah di Jawa Barat dan Jawa Tengah yang terinfeksi OYDV dan SYSV. Berbeda dengan Klukackova et al. (2004) yang melaporkan bahwa infeksi SLV dan GCLV seringkali tidak menunjukkan gejala visual yang jelas. Oleh karena itu untuk menentukan virus-virus yang menginfeksi bawang di lapangan, deteksi di laboratorium menggunakan metode yang akurat dan cukup sensitif perlu dilakukan, misalnya dengan metode ELISA menggunakan antibodi spesifik. Potyvirus yang banyak dilaporkan menginfeksi bawang merah dan bawang putih 
Tabel 3 Frekuensi insidensi virus pada sampel umbi bawang berdasarkan hasil deteksi dengan metode ELISA

\begin{tabular}{|c|c|c|c|c|c|c|c|c|c|}
\hline \multirow{2}{*}{$\begin{array}{c}\text { Jenis } \\
\text { dan asal } \\
\text { sampel } \\
\text { lapangan }\end{array}$} & \multirow[b]{2}{*}{ Varietas } & \multicolumn{7}{|c|}{$\sum$ sampel positif ELISA/ $\sum$ sampel yang diuji (\%) } & \multirow{2}{*}{$\begin{array}{c}\text { Rata-rata } \\
\text { insidensi } \\
\text { virus pada } \\
\text { masing- } \\
\text { masing } \\
\text { lokasi }\end{array}$} \\
\hline & & GCLV & SLV & Potyvirus & $\begin{array}{c}\text { GCLV, } \\
\text { SLV }\end{array}$ & $\begin{array}{c}\text { GCLV, } \\
\text { Potyvirus }\end{array}$ & $\begin{array}{c}\text { SLV, } \\
\text { Potyvirus }\end{array}$ & $\begin{array}{c}\text { GCLV, } \\
\text { SLV, dan } \\
\text { Potyvirus }\end{array}$ & \\
\hline BM & Tidak & $0 / 14$ & $0 / 14$ & $6 / 14$ & $0 / 14$ & $0 / 14$ & $5 / 14$ & $0 / 14$ & 133 \\
\hline Bogor & diketahui & $(0)$ & $(0)$ & $(42.9)$ & $(0)$ & $(0)$ & (35.7) & $(0)$ & 15.3 \\
\hline $\mathrm{BM}$ & Bima & $1 / 14$ & $1 / 14$ & $2 / 14$ & $1 / 14$ & $3 / 14$ & $0 / 14$ & $5 / 14$ & 133 \\
\hline Brebes & curut & (7.1) & $(7.1)$ & (14.3) & (7.1) & (21.4) & $(0)$ & $(35.7)$ & 10.0 \\
\hline $\mathrm{BM}$ & Bima & $0 / 14$ & $0 / 14$ & $1 / 14$ & $0 / 14$ & $0 / 14$ & $9 / 14$ & $3 / 14$ & 112 \\
\hline Cirebon & curut & $(0)$ & $(0)$ & $(7.1)$ & $(0)$ & $(0)$ & $(64.2)$ & $(21.4)$ & 11.2 \\
\hline $\begin{array}{l}\text { Rata-rata } \mathrm{i} \\
\text { virus targe } \\
\text { bawang } \mathrm{m}\end{array}$ & $\begin{array}{l}\text { infeksi } \\
\text { et pada } \\
\text { erah }\end{array}$ & 2.4 & 2.4 & 21.4 & 2.4 & 7.1 & 33.3 & 19.0 & \\
\hline $\begin{array}{l}\text { BP } \\
\text { Bogor }\end{array}$ & $\begin{array}{c}\text { Tidak } \\
\text { diketahui }\end{array}$ & $\begin{array}{l}1 / 14 \\
(7.1)\end{array}$ & $\begin{array}{r}4 / 14 \\
(28.6)\end{array}$ & $\begin{array}{r}0 / 14 \\
(0)\end{array}$ & $\begin{array}{l}1 / 14 \\
(7.1)\end{array}$ & $\begin{array}{r}0 / 14 \\
(0)\end{array}$ & $\begin{array}{r}2 / 14 \\
(14.3)\end{array}$ & $\begin{array}{l}1 / 14 \\
(7.1)\end{array}$ & 9.18 \\
\hline
\end{tabular}

BM, bawang merah; BP, bawang putih

di antaranya OYDV, SYSV, dan LYSV (Klukackova et al. 2004; Lunello et al. 2007; Gunaeni et al. 2011; Kurniawan dan Suastika 2013). Deteksi menggunakan antibodi spesifik untuk kelompok Potyvirus perlu dilakukan untuk memastikan jenis Potyvirus yang menginfeksi bawang di Jawa Barat dan Jawa Tengah. Sampel yang memberikan reaksi positif terhadap lebih dari satu jenis antibodi menunjukkan gejala yang lebih kompleks dibandingkan dengan sampel yang memberikan reaksi positif terhadap satu jenis antibodi. Gejala mosaik kuning, garis kuning, dan keriting berasosiasi dengan infeksi GCLV, sementara gejala mosaik kuning, keriting, bagian atas daun berlekuk berasosiasi dengan infeksi SLV. Infeksi campuran GCLV dan SLV menghasilkan gejala yang lebih kompleks, yaitu mosaik kuning, garis kuning, keriting, dan bagian atas daun berlekuk. Kondisi yang sama juga ditemukan pada infeksi campuran SLV dan Potyvirus, dan GCLV, SLV, dan Potyvirus. Berdasarkan pengamatan gejala dan hasil deteksi tersebut dapat disimpulkan bahwa infeksi virus pada bawang merah tidak bersifat spesifik untuk suatu virus tertentu.

Mekanisme infeksi virus bawang umumnya terjadi melalui penularan secara mekanis dengan gesekan antardaun, alat perkembangbiakan vegetatif (terbawa umbi), dan penularan melalui vektor (kutudaun dan tungau). Penularan secara mekanis dilaporkan terjadi pada SYSV dan MbFV, sedangkan SLV dan OYDV merupakan virus tular benih. Jenis virus yang ditularkan melalui vektor, yaitu GCLV, LYSV, OYDV, SYSV, dan MbFV (Diekmann 1997). Infeksi virus pada tanaman bawang akan terakumulasi dari satu generasi ke generasi lainnya melalui organ perbanyakan vegetatif (umbi). Virus terbawa umbi (benih) menghambat pertumbuhan tanaman karena virus berkembang bersama. Virus terbawa benih dapat menjadi inokulum primer di lapangan, selanjutnya inokulum dapat menyebar dengan bantuan serangga vektor. Infeksi virus pada tanaman bawang dapat merugikan terutama pada penurunan kualitas dan kuantitas hasil. Ukuran umbi mengecil dan bobot umbi berkurang sehingga harga jual rendah (Sutarya dan Duriat 1991).

Hasil deteksi virus dari umbi yang berasal dari Jawa Barat dan Jawa Tengah menunjukkan potensi umbi sebagai sumber infeksi sejak awal penanaman. Potyvirus yang menginfeksi secara tunggal maupun bersama dengan SLV merupakan insidensi yang dominan pada 
bawang merah di lapangan maupun di tempat penyimpanan. Berbeda dengan bawang putih, infeksi yang dominan ialah SLV pada umbi di tempat penyimpanan dan infeksi ganda GCLV dan Potyvirus pada tanaman di lapangan. Upaya untuk mengurangi sumber penyakit di lapangan dapat dilakukan dengan menerapkan sistem sertifikasi bibit sehat dengan menanam umbi bibit bebas virus.

\section{UCAPAN TERIMA KASIH}

Penulis mengucapkan terima kasih kepada ACIAR atas dukungannya melalui kegiatan kerja sama penelitian berjudul Increasing Productivity of Allium and Solanaceous Vegetable Crops in Indonesia and SubTropical Australia (Hort/2009/056).

\section{DAFTAR PUSTAKA}

Bagi F, Stojsin V, Budakov D, Salma MAE, Varga JG. 2012. Effect of Onnion yellow dwarf virus (OYDV) on yield components of fall garlic (Allium sativum L.) in Serbia. Afr J Agric Res. 7(15):2386-2390. DOI: http://dx.doi.org/10.5897/AJAR11.1772.

[BPS] Badan Pusat Statistik. 2013. Luas Panen, Produksi, dan Produktivitas Bawang Merah dan Bawang Putih [Internet]. [diunduh 2013 Februari 13]. Tersedia pada: http://www.bps.go.id/tab_ sub?view.php.

Diekmann M. 1997. FAO/IPGRI Technical Guidelines for the Safe Movement of Germplasm. No. 18. Allium spp. Roma (IT): Food and Agriculture Organization of the United Nations, Rome/International Plant Genetik Resources Institute, Rome.
Gunaeni N, Wulandari AW, Duriat AS, Muharam A. 2011. Insiden penyakit tular umbi pada tiga belas varietas bawang merah asal Jawa Barat dan Jawa Tengah. J Hort. 21(2):164-172.

Klukackova J, Navratil M, Vesela M, Havranek P, Safarova D. 2004. Occurrence of garlic viruses in the Czech Republic. Acta Fytotechnica. 16(7):126-128.

Kurniawan A, Suastika G. 2013. Deteksi dan identifikasi virus pada bawang merah. J Fitopatol Indones. 9(2):47-52. DOI: http:// dx.doi.org/10.14692/jfi.9.2.47.

Lunello P, Rienzo JD, Conci VC. 2007. Yield loss in garlic by Leek yellow stripe virus Argentina isolate. Plant Dis. 91(2):153158. DOI: http://dx.doi.org/10.1094/PDIS91-2-0153.

Sutarya R, Duriat AS. 1991. Respon beberapa kultivar cabai terhadap Cucumber mosaic virus (CMV), Tobacco etch virus (TEV) dan campuran dari CMV+TEV. Bull Penel Hort. 21(1):72-76.

Torrico AK, Cafrune EE, Conci VC. 2010. First report of Shallot latent virus on garlic in Argentina. Plant Dis. 97(7):915. DOI: http://dx.doi.org/10.1094/PDIS-94-70915B. 